\title{
Healthy Lifestyle Model among Benha University Town Students
}

\section{Noha Shawkey Mostafa ${ }^{1}$, Howyida Sadek Abd El-Hameed ${ }^{2}$, Ahlam Elahmady Mohamed ${ }^{3}$ and Huda Abdalla Mursei ${ }^{4}$}

(1) Nursing educator at Technical School of Nursing at Shebin El- Kom-Menofiya Governorate, Egypt, (2) Professor of Community Health Nursing, Faculty of Nursing, Benha University, Egypt , (3)Assistant Professor of Community Health Nursing, Faculty of Nursing, Benha University, Egypt and (4) Lecturer of Community Health Nursing, Faculty of Nursing, Benha University, Egypt

\begin{abstract}
Background: University towns are responsible for the creation of a supportive environment for the health promotion and helping students manage and control their health. Healthy lifestyle behaviors involve a set of students' choices in the status of life that influences the health of the student. Aim of study: Was to evaluate the effect of healthy lifestyle model among Benha university town students. Research design: A Quasi experimental research design was used. Setting: This study was conducted at Benha University Town, Benha City. Sample: A simple random sample of 149 university town students. Tools: Three tools were used for data collection. I: An interviewing questionnaire. II: Healthy life style scale for university students to assess student's healthy life style and III: Observational checklist questionnaire to assess Benha University town environment which included 3 items as (buildings, rooms, kitchen). Results: There was significant improvement of studied student's total knowledge post implementation of healthy lifestyle model to reach $77 \%$ compared by $68 \%$ pre the implementation. Also, there was significant improvement of studied student's total lifestyle post implementation of healthy lifestyle model to reach $81 \%$ compared by $74 \%$ pre the implementation. Conclusion: Healthy lifestyle plays a key role in improving life and health of university town students. The most common factors predisposing to unhealthy lifestyle among university town students not being able to manage their time and routine, problem of individualism and self-centered attitudes and absence of a door to knock upon whenever they wish to resolve their problems of health, social life, and academics. Recommendation: The health education agenda should focus on themes such as hygiene, physical activity, nutrition and relationships. "Stress management" and "time management" taught along with curricula may assist students in dealing with stress caused by heavy loads of study. Further studies are needed to ensure the importance of healthy lifestyle model among university town students.
\end{abstract}

Keywords: University town, healthy lifestyle.

\section{Introduction:}

Lifestyle of college students are of great importance due to the fact that data about the lifestyle and risk behaviors of this sensitive group of population is limited. The health habits of the college students can affect their health in the future. College years are great times to develop new habits that will help the students to strengthen their health through the college years and beyond (Center of Disease Control, 2018). College students' lives are very busy because of many work; going out with friends in addition to attending school and studying. Being able to balance all of these actions presents a very stressful lifestyle for many college students. Here comes the importance of having a healthy lifestyle, because college students' 
health needs to be the best it can be in order for their bodies and minds to function effectively (Budd \& Preston, 2015).

Lifestyle improving activities include proper nutrition and exercise, healthy sleep patterns and adequate rest, healthy coping with stress, and ability to use family and community supports and resources. Health promotion programs in the community may address such habits. Lifestyle improving activities include meaningful work, whether through or outside employment, creative outlets, interpersonal relationships, recreational activities, and opportunities for spiritual and intellectual growth. Mental health promotion interventions can address such behaviors (Allender \& Spradley, 2015).

Personal health habits of university residence continue to contribute to the major causes of morbidity and mortality. The pattern of personal health habits and risk behaviors defines student and family lifestyle risk. The family is the basic unit within which health behavior, including health values, health habits, and health risk perceptions is developed, organized, and performed. Families maintain major responsibility for determining what food is purchased and prepared, setting sleep patterns, planning family activities, setting and monitoring norms about health and health risk behaviors, determining when a family member is ill, when health care should be obtained, and carrying out treatment regimens (Stanhope \& Lancaster, 2016).

Teaching healthy lifestyle model in the university town residence is an ideal and cost-effective means of developing healthy lifestyles, because university students are in a unique stage of knowledge absorption and personality shaping. Hsiao et al., 2015 reported educational study significant increases in the total and subscale score averages of healthy life style behavior. These behavior patterns and their consequences typically persist into adulthood, jeopardizing individuals' health status in later life (Pender et al., 2011).

Lifestyle assessments and wellness inventories are wellness-focused appraisals that place greater emphasis on promoting health of university town residence rather than identifying risk factors for specific diseases. Lifestyle assessments focus on daily patterns of behavior that affect health and over which the individual has some control. Health risk appraisals enable the community health nurse to individualize assessment of risks and to recommend behavior changes compatible with a healthier lifestyle (Smith \& Maurer, 2019).

Community health nurse emphasizes on positive changes to a healthy lifestyle behaviors of students after the education given to students to increase their healthy lifestyle behaviors. Community health nursing are key to improving young people's health and wellbeing by delivering health promotion, providing health advice, signposting to other services, active treatment, education, family support, protection, safeguarding, service coordination and multiagency work. Many studies have shown that the health behavior is modulated by the sociodemographical variables, such as gender, age, socio-economic level, ethics, examination level at admission, and educational level of their parents (Kandari \& Vidal, 2017).

\section{Significance of the study:}

Healthy behaviors are helping students to avoid diseases, remain strong, and maintain their physical and mental health (Van \& Surujlal, 2013). In Egypt, the number of university students for both sex in 2017-2018 based upon data of National Center Registry Program (NCRP) was 2.5 million university student about two third of this number occupy the university town cities (Ibrahim et al., 
2017). So this study is important because healthy choices today influence health for the rest of one's life. In other words, new behaviors and lifestyle patterns (e.g. excessive alcohol use, tobacco use, inactivity, and unhealthy dietary practices) formed during university life are likely to be sustained into adulthood.

\section{Aim of the study:}

This study aimed to evaluate the effect of healthy lifestyle model among Benha university town.

\section{Research Hypothesis}

Benha university town students' knowledge and practice regarding their lifestyle would be improved after the implementation of healthy lifestyle model.

\section{Subject and methods:}

\section{Research design:}

Quasi experimental design was used in carrying out this study.

\section{Setting:}

The study was conducted at Benha University Town in Benha City.

\section{Sampling:}

Simple random sample was used from about $50 \%$ of third \& fourth grade Benha university town students. The total number of study sample was selected from 300 students both male and female in third \&fourth grade is 149 students (62 male students out of 125 student \& 87 female students out of 175 students). It was difficult to work with the agreed number of students (149) as the student capacity of the University City has decreased to half in light of the precautionary measures of the Corona pandemic.

\section{Tools for Data Collection:}

Three tools were used for data collection:

\section{Tool (I): A structured Interviewing} questionnaire: It consists of four parts to assess the following:
First part: Personal and demographic characteristics data of the university town students involved in the study It included 4 items as; age, sex, faculty name, and grade.

Second part: Medical history of university town students which included 8 items such as; general health status, suffer from headache, suffer from anorexia, suffer from intestinal disturbance (diarrhea), suffer from constipation, suffer from insomnia, suffer from continuous exhaustion, and whether suffer from mood swing.

Third part: Student anthropometric measurement which included 3 items such as; height, weight, and body mass index.

Fourth part: Knowledge of students with healthy lifestyle which included 30 items.

\section{Scoring system:}

The scoring system for students' knowledge was calculated as follows (2) score for complete correct answer, while (1) score for incomplete correct answer and (0) for don't know answer. The total knowledge score $=(60)$ and classified as the following:

1) Good when the total score was $75 \%$ to $100 \%$.

2) Average when the total score was 50 to less than $75 \%$.

3) Poor when the total score was less than $50 \%$.

Tool II: Healthy Life Style Scale for University Students (HLSUS) which included (38) items (adopted from Wang et al., 2013). The questionnaire was measured on a likert type scale of (never, rarely, sometimes, a lot, very much).

- Exercise behavior which included 4 items.

- Regular behavior which included 4 items.

- Nutrition behavior which included 4 items.

- Health risk behavior which included 4 items. 
- Health responsibility which included 6 items.

- Social support which included 4 items.

- Stress management which included 5 items.

- Life appreciation which included 4 items. Scoring system:

Healthy Life Style Scale for University Students score was calculated as follows (4) score for very much, (3) score for a lot, (2) for sometimes, (1) score for rarely and (0) for never. The Healthy Life Style Scale for University Students score $=(152)$ and classified as the following:

1) Good when the total score was $75 \%$ to $100 \%$.

2) Average when the total score was 50 to less than $75 \%$.

3) Poor when the total score was less than $50 \%$.

Tool III: Observational checklist questionnaire to assess Benha University town environment which included 3 items as (buildings, rooms, kitchen).

-Characteristic of University Town building which included (garden surrounding the building, hall for watching T. V, places for studying equipped with adequate light\& ventilation, places for practicing sport).

-Characteristic of university town rooms which included (appropriate number of rooms inside the floor, sufficient number of beds inside the room, appropriate space between beds).

-Characteristic of university town kitchen which included (three meals are served daily, the food is cooked well, fruits \& vegetables are washed well, meals are served in a clean way, university restaurant is always clean).

\section{Scoring system:}

The scoring system observational checklist questionnaire was calculated as follows (1) score for present, while (0) score for not present. The total observational checklist score $=(40)$ and classified as the following:

1) Satisfactory when the total score was $>60 \%$.

2) Unsatisfactory when the total score was less than $>60 \%$.

\section{Validity of the tools:}

Content validity of tools was done by five of Faculty Staff Nursing experts from Community Health Nursing Department who reviewed the tools for clarity, relevance, comprehensiveness, applicability and gave their opinion.

Reliability and content validity of the tools:

Reliability of the tool was applied by the researcher for testing the internal consistency of the tool by administration of the same tools to the same subjects under similar conditions on one or more occasion. Answers from repeated testing were compared (Test- Retest reliability). The reliability was done by Cronbach's Alpha coefficient test which revealed that each of three tools consisted of relatively homogenous items as indicated by the moderate to higher reliability of each tool. The consistency of the knowledge was 0.89 and healthy lifestyle of university students was 0.85 .

\section{Ethical consideration:}

An approval to conduct the study was obtained from the authorized personnel (Head of Benha University City) concerned the title, objectives and tools. The study technique was illustrated to gain their cooperation which is needed to allow the researcher to meet the studied sample at chosen setting. The agreement for participation was taken orally before conducting the interview and given a brief orientation to the purpose of the study. The studied students were also reassured that all information gathered would be confidentially and used only for the purpose of the study. No names required on the forms 
to ensure anonymity and confidentiality. They were also informed about their right to withdraw at any time from the study without giving any reasons.

\section{Pilot study:}

Before starting data collection, a pilot study was conducted using the tools on 10 participants (10\% of the study sample). The pilot study was carried out to test the applicability and clarity of the constructed questionnaire and detect any obstacles or problems that might arise during the actual collection of data. Also, to estimate the time needed to fill the sheet with the total sample of the study the necessary modification and clarification was done.

\section{Field work:}

\section{Data collection procedure:}

- Data was collected over 5 months from the first of October 2020 and completed by the end of February 2021. The researcher visited Benha university town two days per week (Saturday and Thursday) from 12:00 am to 3:00 pm to accomplish data collection. The average time needed for the sheet was 15- 30 minutes, the average number interviewed at university town were 25 students per day depending on their response of the interviewers. The researcher implemented the intervention through 4 phases as the following:

- Assessment phase: in this phase the researcher assessed knowledge, practices and healthy lifestyle of the studied students through collection analysis baseline data from the filled tools. The researcher did the pre-test.

- Planning phase: The researcher identified the important needs for target group, set priorities of needs, goals and objectives were developed.

- Implementation phase: In this phase the researcher implemented the intervention through five sessions (Theoretical \& Practical), each session lasted 30- 45 minutes and immediately did the post test.

- First session: At the beginning of the first session, an orientation to the intervention, definition of healthy lifestyle, healthy lifestyle domains and benefits, taking into consideration the use of simple language. Motivation, open discussion and reinforcement were used during the lecture to enhance learning. Each session started with a summary about what had been given through the previous session and objectives of new topics. At the end of each session, students participated in a discussion to correct any misunderstanding. Also, they were informed about the time of next session.

- Second session covered importance of exercise behavior (benefits of exercise to both general \& mental health) and importance of regular behavior.

- Third session covered importance of healthy nutrition (eat 5 small frequent meals, well balanced rich in vitamin, minerals, protein, starch, fruit\& vegetables) and avoidance of health risk behavior (smoking cigerrates, stay awake for late times, listen continuously to headphones).

- Fourth session covered responsibility for health (go to the doctor when any unusual sign or symptom appears\& comply with doctors' advice and treatment) and social support (talk about troubles with others \& actively help roommate in trouble).

- Fifth session covered importance of stress management (fix a time for daily relaxation\& accept unchangeable things in life) and life appreciation (feel content \& make an effort to feel growth in a positive direction). 
- Teaching methods:- All students received the same intervention instructions content using the same teaching methods, which were

- Lecture \& discussion.

- Demonstration and re-demonstration.

- Presentation.

Teaching aids:-

- Suitable teaching aids were specially selected for nursing intervention construction as follow:

- Booklets \& pictures.

- Laptop.

- Handouts.

- Evaluation phase: Evaluation of nursing model construction was done by using the post-test questionnaire which was the same format of pre-test questionnaire in order to compare the change of students' knowledge and practices immediately after implementation of nursing intervention construction.

\section{Statistical Analysis:}

- Data was coded and transformed into specially designed form to be suitable for computer entry process. Data was entered and analyzed by using SPSS (Statistical Package for Social Science) version 21. Graphics were done using Excel program. Quantitative data were presented by mean (X) and standard deviation (SD). It was analyzed using student $t$ - test for comparison between two mean, however, if the data was not normally distributed, non-parametric tests were used. Qualitative data were presented in the form of frequency distribution tables, number and percentage. It was analyzed by chi-square $(\chi 2)$ test. However, if an expected value of any cell in the table was less than 5, Fisher Exact test was used. Level of significance was set as $\mathrm{P}$ value $<0.05$ for all significant tests.
Significance level was considered as follow:

- Highly statistically significant P- value $\leq$ $0.001 * *$

- Statistically significant $\mathrm{P}$ - value $<0.05 *$

- Not significant P-value $>0.05$

Results:

Table (1): Showed that, $70 \%$ of the studied students aged from $20-<21$ years with mean age \pm SD $21.1 \pm .1 .1$ years. $68 \%$ of them at fourth academic year. Regarding to sex, $60 \%$ of the students were females, while $42 \%$ of them from faculty of medicine.

Table (2): Showed that, there was a marked improvement in total students' knowledge post implementation of healthy lifestyle model with a highly statistically significant difference at $(\mathrm{P}=<0.01)$ between pre- and post-implementation of healthy lifestyle model. As evidence, $68 \%$ of the studied students have average level of total knowledge pre-implementation of healthy lifestyle model. While, $77 \%$ of them have good level of total knowledge postimplementation of healthy lifestyle model.

Figure (1): This figure showed that, there was significant improvement of studied student's total knowledge post implementation of HLSM to reach $77 \%$ compared by $68 \%$ pre the implementation.

Table (3): Showed that, there was a marked improvement in total students' life style post implementation of healthy lifestyle model with a highly statistically significant difference at $(\mathrm{P}=<0.01)$ between pre- and post-implementation of healthy lifestyle model.

Figure (2): This figure showed that, there was significant improvement of studied student's total lifestyle post implementation of HLSM to reach $81 \%$ compared by $74 \%$ pre the implementation.

Table (4): Showed that, there was a highly statistically significant relation between total students' knowledge at post-implementation 


\section{$\underline{\text { Healthy Lifestyle Model among Benha University Town Students }}$}

and their personal data as sex at $(\mathrm{P}=<0.01)$. While, there was no statistically significant relation with their age, grade and faculty name at $(\mathrm{P}=>0.05)$.

Table (5): Revealed that, there was a highly statistically significant relation between total students' lifestyle at preintervention and faculty name at $(\mathrm{P}=<0.01)$, while there was a highly statistically significant relation between total students' knowledge at post-intervention and their sex at $(\mathrm{P}=<0.01)$. Also, there was statistically significant relation with their faculty name at $(\mathrm{P}=<0.05)$.

Table (6): Showed that, there was a highly statistically significant positive correlation between total students' knowledge and total lifestyle at pre and post- implementation of healthy lifestyle model at $(\mathrm{P}$-value $=<0.01)$.

Table (1): Frequency distribution of the studied students according to their personal data $(\mathbf{n}=\mathbf{1 0 0})$.

\begin{tabular}{|c|c|}
\hline Personal data & $\%$ \\
\hline $\begin{array}{c}\text { Age (years) } \\
20<21 \\
21<22 \\
\geq 22 \\
\text { Mean }+ \text { SD }\end{array}$ & $\begin{array}{c}70 \\
20 \\
10 \\
21+1+1\end{array}$ \\
\hline $\begin{array}{c}\text { Study Grade } \\
\text { Third year } \\
\text { Fourth year }\end{array}$ & $\begin{array}{l}32 \\
68\end{array}$ \\
\hline $\begin{array}{ll}\text { Sex } & \\
& \text { Male } \\
& \text { Female }\end{array}$ & $\begin{array}{l}40 \\
60\end{array}$ \\
\hline $\begin{array}{l}\text { Faculty name } \\
\text { Faculty of medicine } \\
\text { Faculty of science } \\
\text { Faculty of nursing }\end{array}$ & $\begin{array}{l}42 \\
28 \\
30\end{array}$ \\
\hline
\end{tabular}

Table (2): Frequency distribution of studied student total knowledge regarding healthy lifestyle pre $\&$ post implementation $(n=100)$.

\begin{tabular}{|c|c|c|c|c|c|c|c|c|c|c|c|c|c|c|}
\hline \multirow[t]{3}{*}{ Items } & \multicolumn{6}{|c|}{ Pre-program } & \multicolumn{6}{|c|}{ Post program } & \multirow[t]{3}{*}{$\mathrm{X}^{2}$} & \multirow{3}{*}{$\begin{array}{c}\text { p- } \\
\text { value }\end{array}$} \\
\hline & \multicolumn{2}{|c|}{ Good } & \multicolumn{2}{|c|}{ Average } & \multicolumn{2}{|c|}{ Poor } & \multicolumn{2}{|c|}{ Good } & \multicolumn{2}{|c|}{ Average } & \multicolumn{2}{|c|}{ Poor } & & \\
\hline & $\mathbf{N}$ & $\%$ & $\overline{\mathbf{N}}$ & $\%$ & $\mathbf{N}$ & $\%$ & $\mathbf{N}$ & $\%$ & $\mathbf{N}$ & $\%$ & $\mathbf{N}$ & $\%$ & & \\
\hline Healthy lifestyle & 16 & 16 & 64 & 64 & 20 & 20 & 62 & 62 & 34 & 34 & 4 & 4 & 46.97 & $.000 * *$ \\
\hline Exercise behavior & 11 & 11 & 68 & 68 & 21 & 21 & 74 & 74 & 22 & 22 & 4 & 4 & 81.76 & $.000 * *$ \\
\hline Regular behavior & 12 & 12 & 68 & 68 & 20 & 20 & 78 & 78 & 18 & 18 & 4 & 4 & 88.13 & $.000 * *$ \\
\hline Nutrition behavior & 10 & 10 & 74 & 74 & 16 & 16 & 76 & 76 & 19 & 19 & 5 & 5 & 88.94 & $.000 * *$ \\
\hline Health risk behavior & 13 & 13 & 72 & 72 & 15 & 15 & 78 & 78 & 18 & 18 & 4 & 4 & 85.19 & $.000 * *$ \\
\hline Health responsibility & 9 & 9 & 70 & 70 & 21 & 21 & 79 & 79 & 18 & 18 & 3 & 3 & 99.90 & $.000 * *$ \\
\hline Social support & 10 & 10 & 74 & 74 & 16 & 16 & 76 & 76 & 20 & 20 & 4 & 4 & 88.87 & $.000 * *$ \\
\hline Stress management & 12 & 12 & 69 & 69 & 19 & 19 & 75 & 75 & 21 & 21 & 4 & 4 & 81.00 & $.000 * *$ \\
\hline Life appreciation & 10 & 10 & 69 & 69 & 21 & 21 & 75 & 75 & 22 & 22 & 3 & 3 & 87.48 & $.000 * *$ \\
\hline Total knowledge & 11 & 11 & 68 & 68 & 21 & 21 & 77 & 77 & 19 & 19 & 4 & 4 & 57.60 & $.000 * *$ \\
\hline
\end{tabular}




\section{Total level of knowledge about life}

\section{style}

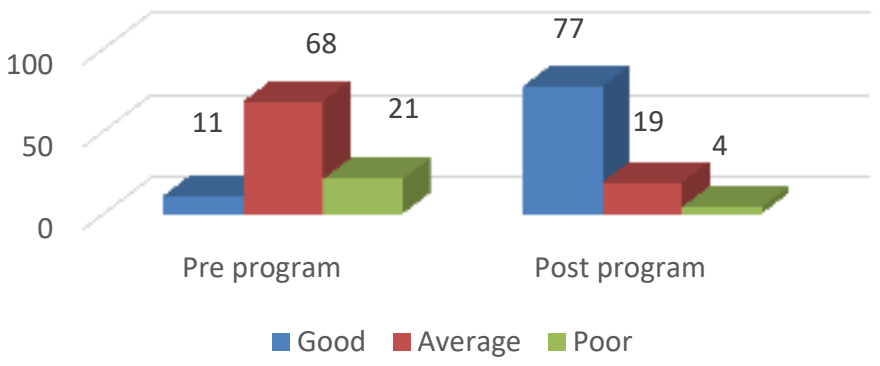

Figure (1): Frequency distribution of the studied students according to their total knowledge about life style pre and post implementation of the healthy lifestyle model $(n=100)$.

Table (3): Frequency distribution of the studied students on total students' life style pre and post implementation regarding the healthy lifestyle model $(n=100)$.

\begin{tabular}{|c|c|c|c|c|c|c|c|c|c|c|}
\hline \multirow[t]{3}{*}{ Items } & \multicolumn{4}{|c|}{ Pre-program } & \multicolumn{4}{|c|}{ Post program } & \multirow[t]{3}{*}{$\mathbf{X}^{2}$} & \multirow[t]{3}{*}{ p-value } \\
\hline & \multicolumn{2}{|c|}{ Healthy } & \multicolumn{2}{|c|}{ Unhealthy } & \multicolumn{2}{|c|}{ Healthy } & \multicolumn{2}{|c|}{ Unhealthy } & & \\
\hline & $\mathbf{N}$ & $\%$ & $\mathbf{N}$ & $\%$ & $\mathbf{N}$ & $\%$ & $\mathbf{N}$ & $\%$ & & \\
\hline Exercise behavior & 11 & 11 & 89 & 89 & 74 & 74 & 26 & 26 & 81.20 & $.000 * *$ \\
\hline Regular behavior & 21 & 21 & 79 & 79 & 80 & 80 & 20 & 20 & 69.62 & $.000 * *$ \\
\hline Nutrition behavior & 28 & 28 & 72 & 72 & 74 & 74 & 26 & 26 & 42.33 & $.000 * *$ \\
\hline Health risk behavior & 82 & 82 & 18 & 18 & 98 & 98 & 2 & 2 & 14.22 & $.000 * *$ \\
\hline Health responsibility & 24 & 24 & 76 & 76 & 60 & 60 & 40 & 40 & 26.60 & $.000 * *$ \\
\hline Social support & 25 & 25 & 75 & 75 & 82 & 82 & 18 & 18 & 65.30 & $.000 * *$ \\
\hline Stress management & 28 & 28 & 72 & 72 & 81 & 81 & 19 & 19 & 56.63 & $.000 * *$ \\
\hline Life appreciation & 15 & 15 & 85 & 85 & 78 & 78 & 22 & 22 & 79.77 & $.000 * *$ \\
\hline Total life style & 26 & 26 & 74 & 74 & 81 & 81 & 19 & 19 & 70.91 & $.000 * *$ \\
\hline
\end{tabular}

(**) highly statistically significant at $\mathbf{p}<0.01$.

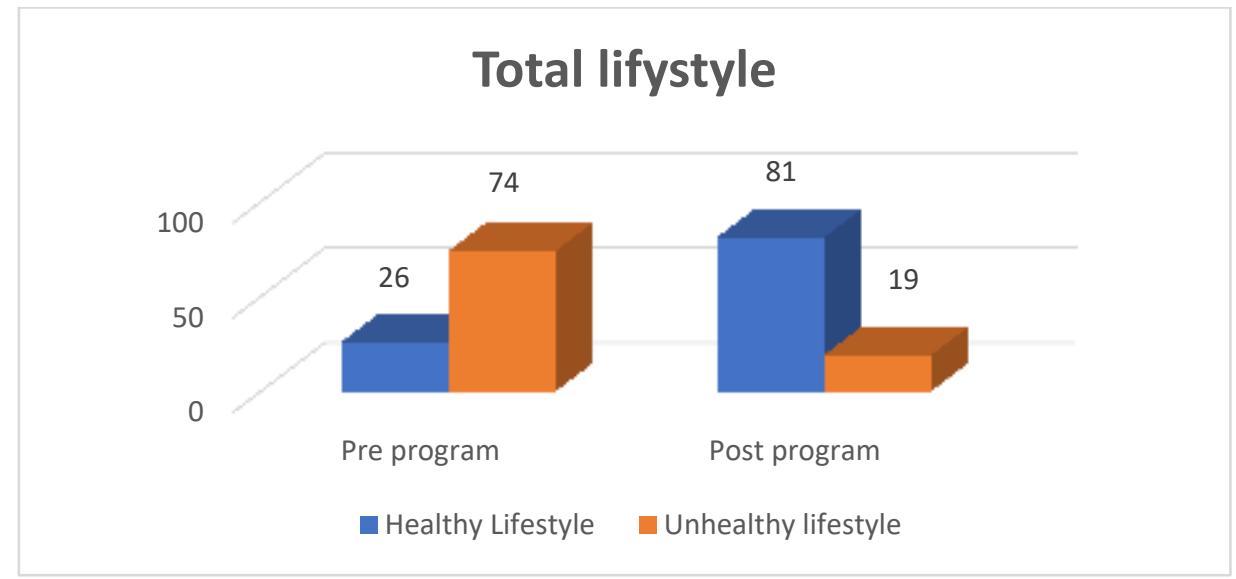

Figure (2): Percentage distribution of the studied students according to their total life style pre and post implementation of the healthy lifestyle model $(n=100)$. 


\section{Healthy Lifestyle Model among Benha University Town Students}

Table (4): Relation between personal data of the studied students and their levels of knowledge at pre and post implementation of the healthy lifestyle model $(n=100)$.

\begin{tabular}{|c|c|c|c|c|c|c|c|c|c|c|c|c|c|c|c|c|c|}
\hline \multirow{3}{*}{\multicolumn{2}{|c|}{ Personal data }} & \multicolumn{6}{|c|}{$\begin{array}{l}\text { Levels of total knowledge at } \\
\text { pre-implementation of } \\
\text { healthy lifestyle model }\end{array}$} & \multirow[t]{3}{*}{$\mathrm{X} 2$} & \multirow[t]{3}{*}{$\begin{array}{c}\text { P- } \\
\text { Valu } \\
\text { e }\end{array}$} & \multicolumn{6}{|c|}{$\begin{array}{l}\text { Levels of total knowledge } \\
\text { at post implementation of } \\
\text { healthy lifestyle model }\end{array}$} & \multirow[t]{3}{*}{$\mathrm{X} 2$} & \multirow[t]{3}{*}{$\begin{array}{l}\text { P- } \\
\text { Val } \\
\text { ue }\end{array}$} \\
\hline & & \multicolumn{2}{|c|}{$\begin{array}{c}\text { Poor } \\
(\mathbf{n}=21)\end{array}$} & \multicolumn{2}{|c|}{$\begin{array}{c}\text { Average } \\
(n=68)\end{array}$} & \multicolumn{2}{|c|}{$\begin{array}{c}\text { Good } \\
(n=11)\end{array}$} & & & \multicolumn{2}{|c|}{$\begin{array}{l}\text { Poor } \\
(n=4)\end{array}$} & \multicolumn{2}{|c|}{$\begin{array}{c}\text { Average } \\
(n=19)\end{array}$} & \multicolumn{2}{|c|}{$\begin{array}{c}\text { Good } \\
(\mathbf{n}=77)\end{array}$} & & \\
\hline & & $\mathbf{N}$ & $\%$ & $\mathbf{N}$ & $\%$ & $\mathbf{N}$ & $\%$ & & & $\mathbf{N}$ & $\%$ & $\mathbf{N}$ & $\%$ & $\mathbf{N}$ & $\%$ & & \\
\hline \multirow{3}{*}{$\begin{array}{l}\text { Age } \\
\text { (years) }\end{array}$} & $20-<21$ & 12 & 57.1 & 56 & 96.6 & 2 & 18.2 & \multirow[t]{3}{*}{$\overline{0.073}$} & \multirow[t]{3}{*}{0.964} & 2 & 50 & 1 & 52.6 & 58 & 75.3 & \multirow[t]{3}{*}{1.518} & \multirow[t]{3}{*}{$\overline{0.468}$} \\
\hline & $21-<22$ & 6 & 28.6 & 8 & 11.8 & 6 & 54.5 & & & 1 & 25 & 6 & 31.6 & 13 & 16.9 & & \\
\hline & $\geq 22$ & 3 & 14.3 & 4 & 5.9 & 3 & 27.3 & & & 1 & 25 & 3 & 15.8 & 6 & 7.8 & & \\
\hline \multirow{2}{*}{$\begin{array}{l}\text { Grad } \\
\text { e }\end{array}$} & Third year & 10 & 47.6 & 18 & 26.5 & 4 & 36.4 & \multirow[t]{2}{*}{3.406} & \multirow[t]{2}{*}{0.182} & 0 & 0.0 & 4 & 21.1 & 28 & 36.4 & \multirow[t]{2}{*}{2.667} & \multirow[t]{2}{*}{.267} \\
\hline & $\begin{array}{l}\text { Fourth } \\
\text { year }\end{array}$ & 11 & 52.4 & 50 & 73.5 & 7 & 63.6 & & & 4 & 100 & 15 & 78.9 & 49 & 63.6 & & \\
\hline \multirow[t]{2}{*}{ Sex } & Male & 3 & 14.3 & 26 & 38.2 & $\begin{array}{l}1 \\
1\end{array}$ & $\begin{array}{c}100 . \\
0\end{array}$ & \multirow{2}{*}{22.37} & \multirow{2}{*}{.000* } & 4 & 100 & 14 & 73.7 & 22 & 28.6 & \multirow{2}{*}{19.17} & \multirow{2}{*}{.000* } \\
\hline & Female & 18 & 85.7 & 42 & 61.8 & 0 & 0.0 & & & 0 & 0.0 & 5 & 26.3 & 55 & 71.4 & & \\
\hline \multirow[t]{3}{*}{\begin{tabular}{|l|} 
Facult \\
y name
\end{tabular}} & $\begin{array}{l}\text { Faculty of } \\
\text { medicine }\end{array}$ & 9 & 42.9 & 28 & 41.2 & 5 & 45.5 & \multirow{3}{*}{1.08} & \multirow{3}{*}{$\mathbf{0 . 8 9 7}$} & 1 & 25.0 & 7 & 36.8 & 34 & 44.2 & \multirow{3}{*}{1.588} & \multirow{3}{*}{0.811} \\
\hline & $\begin{array}{c}\text { Faculty of } \\
\text { science }\end{array}$ & 5 & 23.8 & 21 & 30.9 & 2 & 18.2 & & & 2 & 50.0 & 5 & 26.3 & 21 & 27.3 & & \\
\hline & $\begin{array}{c}\text { Faculty of } \\
\text { nursing }\end{array}$ & 7 & 33.3 & 19 & 27.9 & 4 & 36.4 & & & 1 & 25.0 & 7 & 36.8 & 22 & 28.6 & & \\
\hline
\end{tabular}

No significant at $p>0.05$. **Highly significant at $p<0.01$.

Table (5): Relationship between personal data of the studied students and their levels of lifestyle at pre and post implementation of the healthy lifestyle model $(n=100)$.

\begin{tabular}{|c|c|c|c|c|c|c|c|c|c|c|c|c|c|}
\hline \multirow{3}{*}{\multicolumn{2}{|c|}{ Personal data }} & \multicolumn{4}{|c|}{$\begin{array}{c}\text { Levels of total } \\
\text { lifestyle at pre- } \\
\text { implementation of } \\
\text { healthy lifestyle } \\
\text { model }\end{array}$} & \multirow[t]{3}{*}{$\mathbf{X 2}$} & \multirow[t]{3}{*}{$\begin{array}{c}\text { P- } \\
\text { Value }\end{array}$} & \multicolumn{4}{|c|}{$\begin{array}{c}\text { Levels of total } \\
\text { lifestyle at post } \\
\text { implementation of } \\
\text { healthy lifestyle } \\
\text { model }\end{array}$} & \multirow[t]{3}{*}{$\mathbf{X} 2$} & \multirow[t]{3}{*}{$\begin{array}{l}\text { P- } \\
\text { Val } \\
\text { ue }\end{array}$} \\
\hline & & \multicolumn{2}{|c|}{$\begin{array}{c}\text { Unhealt } \\
\text { hy } \\
(n=74)\end{array}$} & \multicolumn{2}{|c|}{$\begin{array}{c}\text { Healthy } \\
(n=26)\end{array}$} & & & \multicolumn{2}{|c|}{$\begin{array}{c}\text { Unhealt } \\
\text { hy } \\
(n=19)\end{array}$} & \multicolumn{2}{|c|}{$\begin{array}{r}\text { Healthy } \\
(\mathrm{n}=81)\end{array}$} & & \\
\hline & & $\mathbf{N}$ & $\%$ & $\mathbf{N}$ & $\%$ & & & $\mathbf{N}$ & $\%$ & $\mathbf{N}$ & $\%$ & & \\
\hline \multirow{3}{*}{$\begin{array}{l}\begin{array}{l}\text { Age } \\
\text { (years) }\end{array}\end{array}$} & $20-<21$ & 57 & 77 & 13 & 50 & \multirow[t]{3}{*}{1.430} & \multirow[t]{3}{*}{0.232} & 8 & 42.1 & 62 & 76.5 & \multirow[t]{3}{*}{0.739} & \multirow[t]{3}{*}{0.39} \\
\hline & $21-<22$ & 12 & 16.2 & 8 & 30.8 & & & 8 & 42.1 & 12 & 14.8 & & \\
\hline & $\geq 22$ & 5 & 6.8 & 5 & 19.2 & & & 3 & 15.8 & 7 & 8.7 & & \\
\hline \multirow[t]{2}{*}{ Grade } & Third year & 21 & 28.4 & 11 & 42.3 & \multirow{2}{*}{1.716} & \multirow{2}{*}{0.19} & 4 & 21.1 & 28 & 34.6 & \multirow[t]{2}{*}{1.292} & \multirow[t]{2}{*}{0.256} \\
\hline & Fourth year & 53 & 71.6 & 15 & 57.7 & & & 15 & 78.9 & 53 & 65.4 & & \\
\hline \multirow[t]{2}{*}{$\overline{\operatorname{Sex}}$} & Male & 29 & 39.2 & 11 & 42.3 & \multirow[t]{2}{*}{0.078} & \multirow[t]{2}{*}{$\mathbf{0 . 7 8}$} & 2 & 10.5 & 38 & 46.9 & \multirow[t]{2}{*}{8.491} & \multirow{2}{*}{$\begin{array}{c}.004^{*} \\
*\end{array}$} \\
\hline & Female & 45 & 60.8 & 15 & 57.7 & & & 17 & 89.5 & 43 & 53.1 & & \\
\hline \multirow[t]{3}{*}{$\begin{array}{l}\text { Faculty } \\
\text { name }\end{array}$} & $\begin{array}{l}\text { Faculty of } \\
\text { medicine }\end{array}$ & 24 & 32.4 & 18 & 69.2 & \multirow[t]{3}{*}{11.16} & \multirow[t]{3}{*}{$.004 * *$} & 4 & 21.1 & 38 & 46.9 & \multirow[t]{3}{*}{8.939} & \multirow[t]{3}{*}{$.011 *$} \\
\hline & Faculty of science & 23 & 31.1 & 5 & 19.2 & & & 4 & 21.1 & 24 & 29.6 & & \\
\hline & Faculty of nursing & 27 & 36.5 & 3 & 11.5 & & & 11 & 57.9 & 19 & 23.5 & & \\
\hline
\end{tabular}


Table (6): Correlation between total knowledge and total lifestyle among the studied students pre and post implementation healthy lifestyle model $(n=100)$.

\begin{tabular}{|l|c|c|c|}
\hline \multicolumn{2}{|c|}{ Scale } & \multicolumn{2}{c|}{ Total lifestyle } \\
\cline { 3 - 4 } \multicolumn{2}{|c|}{} & Pre-program & Post program \\
\hline Total knowledge & $\mathbf{r}$ & .531 & .691 \\
\cline { 3 - 4 } & $\mathbf{p}$ & $.001^{* *}$ & $.000^{* *}$ \\
\hline
\end{tabular}

**highly significant at $p<0.01$.

\section{Discussion:}

Regarding to demographic characteristics (personal data) of studied university town students, the present study illustrated that less than of the studied students aged $20<21$ years with the mean age 21.1 \pm .1 .1 year. Related to study grade, three fifth of them at fourth year, more than two third of them were female and less than half of them from faculty of Medicine. These findings are congruent with Hacıhasanoğlu et al., (2019), who studied " Healthy lifestyle behavior in university students and influential factors in Eastern Turkey" declared that approximately two-thirds of study students were females, the studied students aged between $21<25$ years, half of them at fourth \& third year and bout two third were medical students.

The current study used a healthy lifestyle model to promote knowledge, practice of university students. After model implementation there was a significant difference in all dimensions of study hypothesis, regarding to knowledge level, the study shows that, more than half of the studied students have average level of total knowledge pre-implementation of healthy lifestyle model. While, three quarter of them have good level of total knowledge postimplementation of healthy lifestyle model. Similarly, Epton et al., (2019), who used educational program with university town students and studied its "Effect on improving knowledge and practice about healthy lifestyle" found that about half of study students $54.6 \%$ have average level of total knowledge pre-intervention Compared by $88,7 \%$ of them have good level of total knowledge post-intervention.

The present study revealed that, two third of the studied students have unhealthy level of total lifestyle pre-implementation of healthy lifestyle model. While, more than three third of them have healthy level of total lifestyle post-implementation of healthy lifestyle model. Similarity, an educational program developed by Wang et al., (2019) "Health promoting lifestyles of university students in Mainland China" the study determined that the mean scores from all dimensions of healthy lifestyle behaviors, were at a medium level (about $63.3 \%$ ) pre implementation while the mean scores increased to reach $85.8 \%$ post implementation.

Regarding studied students and their levels of knowledge at pre and post implementation of the healthy lifestyle model, the present study revealed that, there was a highly statistically significant relation between total students' knowledge at preintervention and their personal data as sex at $(\mathrm{P}=<0.01)$. While, there was no statistically significant relation with their age, grade and faculty name at $(\mathrm{P}=>0.05)$. In addition, the results revealed that, there was a highly statistically significant relation between total students' knowledge at post-intervention and 


\section{$\underline{\text { Healthy Lifestyle Model among Benha University Town Students }}$}

their personal data as sex at $(\mathrm{P}=<0.01)$. While, there was no statistically significant relation with their age, grade and faculty name at $(\mathrm{P}=>0.05)$, female students display an overall healthier profile, whereas it was reported in Peltzer, (2019) study named "Health-promoting lifestyles and personality among black South African students", it was determined in this study that female students were more likely to take a regular behavior, nutrition behavior and health responsibility, and showed more confidence than male students in the social support dimension post intervention. The score average of female students was higher than that of male students in the subscales of self-actualization, health responsibility and nutrition, and interpersonal relations, and physical activity score average was higher in male students compared with female students.

As regards, studied students and their levels of lifestyle at pre and post implementation of the healthy lifestyle intervention, the present study showed that , there was a highly statistically significant relation between total students' lifestyle at pre-intervention and their personal data as faculty name at $(\mathrm{P}=<0.01)$. While, there was no statistically significant relation with their age, grade and sex at $(\mathrm{P}=>0.05)$. In addition, the results revealed that, there was a highly statistically significant relation between total students' knowledge at postintervention and their personal data as sex at $(\mathrm{P}=<0.01)$. Also, there was statistically significant relation with their faculty name at $(\mathrm{P}=<0.05)$. While, there was no statistically significant relation with their age and grade at $(\mathrm{P}=>0.05)$. This result shows similarity with those obtained from some studies conducted in university students, the university students in the medical university are better than students in the three-year college and comprehensive university, which may be because training of medical curriculums make the medical students pay more attention to adopt healthy lifestyle. It also was reported in the study by Can et al., (2018) whose study named "Comparison of the health-promoting lifestyles of nursing and non-nursing students in Istanbul, Turkey" revealed that the nursing students had more positive health-promoting lifestyles. The study also revealed that junior students were far more capable than senior students, which may be because the senior students are engaged in coping with increasing workload and employment stress and had less enthusiasm for university life owing to a longer time of sensitization.

The present study revealed that, there was a highly statistically significant positive correlation between total students' knowledge and total lifestyle at pre and post- healthy lifestyle model at $(\mathrm{P}$-value $=<0.01)$. In the same line Tuğut \& Bekar, (2018) the study named "The relationship between the university students' perception of health and their healthy life style behaviors" reported positive correlation between total students' knowledge and total lifestyle post- healthy lifestyle intervention among university students at $(\mathrm{P}$-value $=<0.05)$.

\section{Conclusion}

Healthy lifestyle plays a key role in improving life and health of University Town students. The most common factors predisposing to unhealthy lifestyle among university town students not being able to manage their time and routine, problem of individualism and self-centered attitudes and absence of a door to knock upon whenever they wish to resolve their problems of health, social life, and academics.

\section{Recommendations:}

The education system, family, and health providers have to take this responsibility jointly as they are the principal 
source of information for the younger population.

Students should be offered more opportunities for recreational and leisure time such as weekly movie shows, event celebrations, excursion tours, and musical concerts.

Physical activities, sports, and socialization are indispensable for individual growth and to foster personal development.

\section{Limitation of the study:}

- It was difficult to work with the agreed number of students (149) as the student capacity of University City has decreased to half in light of the precautionary measures of Corona pandemic.

- It was difficult to reach most of the students as they are out of the University City most of the time.

\section{References}

Allender, J., and Spradeley, B. (2015). Community health nursing; promoting and protecting the public's health. $\left(6^{\text {th }}\right.$ ed.). Philadelphia; Lippinott Williams \& Wilkins. P 403, 841, 845.

Budd, G.,and Preston, D. (2015). College students' attitudes and beliefs about the consequences of smoking: development and normative scores of a new scale. JAANP; May 13 (9): 421-7.

Can, G., Ozdilli, K., and Erol O. (2018). "Comparison of the health-promoting lifestyles of nursing and non-nursing students in Istanbul, Turkey," Nursing and Health Sciences, vol. 10(4): P 273-280.

Center of Disease Control. (2018). College Health and Safety. [online]. Available from: http://www.cdc.gov /family/college/ . [Accessed on 19-12-2018.

Epton, T., Norman, P., Sheeran, P., Harris, P. R., T. L., Ciravegna, F., \& Brennam, A. (2019): Effect of improving knowledge and practice about healthy lifestyle: study protocol. Journal of British Medical Council, 13,107 .

Hacıhasanoğlu, R., Yıldırım, A., Karakurt, P., and Sağlam, R. (2019). "Healthy lifestyle behaviour in university students and influential factors in eastern Turkey," International Journal of Nursing Practice, vol. 17(1):P 43-51.

Hsiao, Y.C. Chen, M.Y. Gau, Y.M. Hung, L.L. Chang, and S.H. Tsai H.M. (2015): "Short-term effects of a health promotion course for Taiwanese nursing students," Public Health Nursing, 22(1) pp. 74-81.

Ibrahim, S., Khaled, M., Nabiel, H., Mikhail, H., Baraka, H., and Kamel H., (2017): Number of university students in Egypt: Results of the National PopulationBased Cancer Registry Program. Journal of Global Statics. Volume 2017, Article ID 437971, 18 pages. Available at: http://dx.doi.org/10.1155/2014/437971.

Kandari, F., and Vidal, L. (2017): "Correlation of the health promoting lifestyle, enrollment level, and academic performance of College of Nursing students in Kuwait," Nursing and Health Sciences, 9(2): P112-119. Peltzer K. (2019). "Health-promoting lifestyles and personality among black South African students," Social Behavior and Personality, vol. 30(4) 4:P. 417-422.

Pender,J., Barkauskas, V., Hayman, L., Rice, V.,. and Anderson, T. (2011): "Health promotion and disease prevention: toward excellence in nursing practice and education," Nursing Outlook, 40(3): P. 106-120.

Smith, C., and Maurer, F. (2019). Community Health Nursing; Theory and practice $\left(2^{\text {nd }}\right.$ ed.). W.B. Saunders Company. Philadelphia. PP449, 452, 55, 465, 466.

Stanhope, M., and Lancaster, J. (2016). Community health nursing; promoting health and aggregates, families, and individuals $\left(4^{\text {th }}\right.$ ed.). St. Lous; Mosby. P 1096, 481-2. 
Tuğut, N., and Bekar, M. (2018). "The relationship between the university students'perception of health and their healthy life style behaviors," Atatürk University Journal of Nursing School, vol. 11: P17-26. Van,T., Rensburg, J., and Surujlal, N. (2013): Gender differences related to the health and lifestyle patterns of university students. Journal of Interdisciplinary Health Science, 18 (1).

Wang, D., Ou, Q., Chen,Y., and Duan, N. (2019). "Health promoting lifestyles of university students in Mainland China," BMC Public Health, vol. 9, article 379. 


\section{نموذج نمط الحياة الصحية بين طلاب المدينة الجامعية بينها}

نهى شوقي مصطفى خاطر - هويدا صـادق عبد الحميد ـ أحلام الاحمدي حمد سرحان- هدى عبد الله مرسي

يشكل طلاب المدينة الجامعية جزءًا كبيرًا من الثباب وهم الفئة المستهدفة في التعليم حول أهمية نمط الحياة الصحية فمن الضروري تعزيز نموهم الصحي من خلال التعديل في نمط حياتهم فالغالبية العظمى من طلاب الجامعة يمارسون الحد الأدنى من السلوكيات المعززة للصحة ويتعرضون لمخاطر صحية و سلوكية كثيرة مثل تدخين السجائر والنظام الغذائي غير السليم والأنشطة البدنية غير السليمة. لذا هدفت هذه الدر اسة الى تقييم نموذج نمط الحياة الصحية بين طلاب المدينة الجامعية ببنها. وقد أجريت هذه الدراسة في المدينة الجامعية بينها على عينة عشو ائية من طلبة الفرقة الثالثة و الرابعة نزلاء المدينة الجامعية بينها. و أظهرت نتائج الدراسة بوجود علاقة ذات دلالة إحصائية بين نمط الحياة غير الصحي و السكن الجامعي. وكانت هنالك علاقة قوية بين نموذج نمط الحياة الصحية وتحسين صحة طلاب المدن الجامعية. كما اوصت الدر اسة بتركيز أجندة التثقيف الصحي على موضو عات مثل النظافة و النشاط البدني و التغذية و العلاقات. كما يجب منح الطلاب المزيد من الفرص للترفيه وقتل الفراغ. 